\title{
A FED-BATCH FERMENTATION PROCESS FOR POLY \\ (3-HYDROXYBUTYRATE-co-3-HYDROXYVALERATE) PRODUCTION BY Yangia sp. ND199 USING MOLASSES AS SUBSTRATE
}

\author{
Doan Van Thuoc ${ }^{1}$, Tran Huu Phong ${ }^{1}$, Dang Minh Khuong ${ }^{2}$ \\ ${ }^{1}$ Hanoi National University of Education, *thuocdv@hnue.edu.vn \\ ${ }^{2}$ Bao Yen 2 High School
}

\begin{abstract}
A locally isolated halophilic bacterium, Yangia sp. ND199 was able to use molasses as substrate for copolymers poly(3-hydroxybutyrate-co-3-hydroxyvalerate) [P(3HB-co-3HV)] production. Cell dry weight (CDW) of $6.37 \mathrm{~g} / 1, \mathrm{P}(3 \mathrm{HB}-\mathrm{co}-3 \mathrm{HV})$ content of $43.1 \mathrm{wt} \%$ and $\mathrm{P}(3 \mathrm{HB}-\mathrm{co}-$ $3 \mathrm{HV}$ ) concentration of $2.75 \mathrm{~g} / \mathrm{l}$ were obtained by Yangia sp. after $60 \mathrm{~h}$ of cultivation in flask. In a batch cultivation mode in a fermentor, the CDW was increased to $9.1 \mathrm{~g} / \mathrm{l}$ but $\mathrm{P}(3 \mathrm{HB}-\mathrm{co}-3 \mathrm{HV})$ content was decreased to $37 \mathrm{wt} \%$. Fed-batch fermentation with two different nutrient feeding strategies was used. High CDW of $54.8 \mathrm{~g} / 1$ was obtained after $54 \mathrm{~h}$ of cultivation but $\mathrm{P}(3 \mathrm{HB}-\mathrm{co}-3 \mathrm{HV})$ content was still low (39.8 wt\%). Two-step fed-batch fermentation with two different nutrient feeding strategies was then designed. High CDW of $50 \mathrm{~g} / 1$ and $\mathrm{P}(3 \mathrm{HB}-\mathrm{co}-3 \mathrm{HV})$ content of $52.9 \mathrm{wt} \%$ were obtained after $54 \mathrm{~h}$ of cultivation. The two-step fed-batch process designed here for the production of $\mathrm{P}(3 \mathrm{HB}-$ co-3HV) by Yangia sp. ND199 can be developed and used for further studies.
\end{abstract}

Keywords: Yangia, fed-batch fermentation, molasses, $\mathrm{P}(3 \mathrm{HB}-\mathrm{co}-3 \mathrm{HV})$.

\section{INTRODUCTION}

Polyhydroxyalkanoates (PHAs) are a group of biodegradable polyesters of biological origin, PHAs accumulate intracellularly as carbon and energy storage materials in many microorganisms, usually when grown under the limitation of a nutrient, such as oxygen, nitrogen, phosphate, sulphur, or magnesium and in the presence of excess carbon $[1,14]$. The properties of PHAs are similar to those of common petrochemical-based synthetic thermoplastics and can hence potentially replace them [9]. Furthermore, these polymers are biocompatible and hence have several medical applications, such as bone plates, osteosynthetic materials, surgical sutures, vascular grafts, heart valves and drug delivery systems [3, 9, 17].

Poly(3-hydroxybutyrate) $[\mathrm{P}(3 \mathrm{HB})]$ is the most common type of PHA and was first described by a French scientist in 1926 [7]. Since then, various bacterial, archaeal and fungal strains have been identified to accumulate $\mathrm{P}(3 \mathrm{HB})$ both aerobically and anaerobically [2]. However, application of this homopolymer is limited as it is highly crystalline, stiff and brittle in nature [9]. These polymer properties can be improved through the incorporation of comonomers, such as 3hydroxyvalerate $(3 \mathrm{HV})$ and 4-hydroxybutyrate (4HB). Copolymers poly(3-hydroxybutyrate-co3 -hydroxyvalerate) $[\mathrm{P}(3 \mathrm{HB}-\mathrm{co}-3 \mathrm{HV})]$ is more flexible and tougher than $\mathrm{PHB}$ and can be applied in many different area [9].

One of the major bottlenecks in the commercial application of PHA is their high price as compared to the conventional petroleum-based plastic materials. Several factors can affect the overall economics of PHA production, these include the yield of PHA on a carbon source, PHA productivity, the price of raw materials, the fermentation technology and purification method employed. About 40-50\% of the total production cost is attributed to the carbon source [94]. Hence, a promising solution for low-cost PHA production is to develop fermentation strategies that allow high PHA content and productivity from cheap carbon substrate.

Recently, several halophilic and halotolerant bacterial strains isolated from mangrove soil samples in Nam Dinh province, Northern Vietnam, were shown to have the ability to accumulate PHAs. Among them, strain Yangia sp. ND199 were found to synthesize the 
copolymer $\mathrm{P}(3 \mathrm{HB}-\mathrm{co}-3 \mathrm{BV})$ when grown on glucose or sucrose as carbon source $[15,16]$. In the present work, we undertaken to find strategies for improving the volumetric productivity of $\mathrm{P}(3 \mathrm{HB}-\mathrm{co}-3 \mathrm{HV})$ by Yangia sp. ND199 using molasses as the carbon source. For this, two-step fed-batch fermentation was designed to attain both high cell density and high $\mathrm{P}(3 \mathrm{HB}-\mathrm{co}-3 \mathrm{HV})$ content.

\section{MATERIALS AND METHODS}

\section{Bacterial strain and maintenance}

Yangia sp. ND199 was maintained on solid $\mathrm{HM}$ medium at $4^{\circ} \mathrm{C}$, containing $(\mathrm{g} / \mathrm{l})$ as follows $\mathrm{NaCl}: 30, \mathrm{MgSO}_{4} .7 \mathrm{H}_{2} \mathrm{O}: 0.25, \mathrm{CaCl}_{2} .2 \mathrm{H}_{2} \mathrm{O}: 0.09$, $\mathrm{KCl}: 0.5$, NaBr: 0.06 , peptone: 5 , yeast extract: 10 , glucose: 1 , and granulated agar: 20 . The $\mathrm{pH}$ of the medium was adjusted to $7.0[10]$.

\section{Molasses}

Molasses from Nordic sugar (Lund, Sweden) was used as carbon source. The molasses contains about $560 \mathrm{~g} / 1$ sucrose.

\section{$\mathbf{P}(3 \mathrm{HB}-\mathrm{co-3BV})$ production in shake flasks}

Yangia sp. ND199 was grown in $20 \mathrm{ml}$ of $\mathrm{HM}$ medium in a $100 \mathrm{ml}$ flask at $32^{\circ} \mathrm{C}$ with rotary shaking at $180 \mathrm{rpm}$ for $13 \mathrm{~h}\left(\mathrm{OD}_{600}=\right.$ 5.0 ). Subsequently, $2.5 \mathrm{ml}$ of each culture broth were inoculated in $250 \mathrm{ml}$ Erlenmeyer flasks containing $50 \mathrm{ml}$ of HM1 medium (table 1). The $\mathrm{pH}$ of this medium was initially adjusted to 7.0 using $1 \mathrm{M} \mathrm{NaOH}$. The cultures were incubated at $32^{\circ} \mathrm{C}$ with rotary shaking at $180 \mathrm{rpm}$. Samples were withdrawn at 12, 24, 36, 48 and $60 \mathrm{~h}$ of cultivation for cell dry weight (CDW) and $\mathrm{P}(3 \mathrm{HB}-\mathrm{co}-3 \mathrm{HV})$ content analysis.

Table 1. Composition of the culture media and feed solution used for $\mathrm{P}(3 \mathrm{HB}-\mathrm{co}-3 \mathrm{HV})$ production by Yangia sp. ND199

\begin{tabular}{lccccc}
\hline Component & $\begin{array}{c}\text { Batch medium } \\
\mathrm{HM} 1(\mathrm{~g} / \mathrm{l})\end{array}$ & $\begin{array}{c}\text { Fed-batch } \\
\text { medium } \\
\mathrm{HM} 2(\mathrm{~g} / \mathrm{l})\end{array}$ & $\begin{array}{c}\text { Feed } \\
\text { solution } \\
\mathrm{I}(\mathrm{g} / \mathrm{l})\end{array}$ & $\begin{array}{c}\text { Feed } \\
\text { solution } \\
\text { II }(\mathrm{g} / \mathrm{l})\end{array}$ & $\begin{array}{c}\text { Feed } \\
\text { solution } \\
\mathrm{III}(\mathrm{g} / \mathrm{l})\end{array}$ \\
\hline $\mathrm{NaCl}$ & 30 & 30 & 30 & 30 & 30 \\
$\mathrm{MgSO}$ & & 1.7 & 10.2 & 10.2 & 10.2 \\
$\mathrm{KCl}$ & 0.25 & 1 & 6 & 6 & 6 \\
$\mathrm{KBr}$ & 0.5 & 0.12 & 0.72 & 0.72 & 0.72 \\
$\mathrm{KH}_{2} \mathrm{PO}_{4} \mathrm{O}$ & 0.06 & 1.1 & 6.6 & 6.6 & 6.6 \\
$\mathrm{CaCl}_{2} \cdot 2 \mathrm{H}_{2} \mathrm{O}$ & 0.25 & 0.18 & 1.08 & 1.08 & 1.08 \\
Peptone & 0.09 & 3 & 18 & - & - \\
Yeast extract & 1 & 6 & 36 & - & - \\
Sucrose in & 1 & 22 & 130 & 130 & - \\
molasses & 22 & - & - & - & 130 \\
Glucose & - & & & & \\
\hline
\end{tabular}

\section{$\mathrm{P}(3 \mathrm{HB}-\mathrm{co-3BV})$ production in batch fermentation}

Yangia sp. ND199 was grown in $200 \mathrm{ml}$ of $\mathrm{HM}$ medium in $1000 \mathrm{ml}$ flask at $32^{\circ} \mathrm{C}$ with rotary shaking at $180 \mathrm{rpm}$ for $13 \mathrm{~h}\left(\mathrm{OD}_{600}=\right.$ 5.0). The $200 \mathrm{ml}$ culture broth was used to inoculate in 5 -L fermentor containing 1.81 of HM1 medium. Temperature during the cultivation was maintained at $32^{\circ} \mathrm{C}$ while $\mathrm{pH}$ was kept constant at 7.0 using $5 \mathrm{M} \mathrm{HCl} / \mathrm{NaOH}$. Stirring velocity and aeration were initially set at $250 \mathrm{rpm}$ and $1 \mathrm{l} / \mathrm{min}$ and increased during the fermentation to maintain the dissolved oxygen concentration above $20 \%$. Samples were taken at different times for $\mathrm{CDW}$ and $\mathrm{P}(3 \mathrm{HB}-\mathrm{Ho}-$ $3 \mathrm{HV}$ ) content analysis.

Production of $\mathrm{P}(3 \mathrm{HB}-\mathrm{co-3BV})$ by fed-batch cultures with two nutrient feeding strategies

Yangia sp. ND199 was grown in $50 \mathrm{ml}$ of $\mathrm{HM}$ medium in $250 \mathrm{ml}$ flask at $32^{\circ} \mathrm{C}$ with rotary shaking at $180 \mathrm{rpm}$ for $13 \mathrm{~h}\left(\mathrm{OD}_{600}=5.0\right)$. The $300 \mathrm{ml}$ culture broth was used to inoculate in 10-L fermentor containing 2.71 of HM2 medium (table 1). Fed-batch cultivations were 
performed under the following conditions: temperature of $32^{\circ} \mathrm{C}, \mathrm{pH} 7.0$ and the dissolved oxygen concentration was kept above $20 \%$. Sucrose concentration was maintained at about of $20 \mathrm{~g} / 1$ by adding the feed solution I during first $24 \mathrm{~h}$ and then the feed solution II until the end of fermentation. Samples were taken at different times for $\mathrm{CDW}$ and $\mathrm{P}(3 \mathrm{HB}-\mathrm{co}-3 \mathrm{HV})$ content analysis.

\section{Two-step fed-batch fermentation for $\mathrm{P}(3 \mathrm{HB}$ - co-3BV) production}

Yangia sp. ND199 was grown in fed-batch fermentation as described above and the feed solution I was used to maintain sucrose concentration at $20 \mathrm{~g} / \mathrm{l}$. After $24 \mathrm{~h}$ of cultivation, cells were harvested by filtration and re-grown in second fed-batch fermentation, feed solution III was used to maintain carbon source concentration around $20 \mathrm{~g} / \mathrm{l}$. Samples were taken at different times for $\mathrm{CDW}$ and $\mathrm{P}(3 \mathrm{HB}-\mathrm{co}-3 \mathrm{HV})$ content analysis.

\section{Quantitative analysis}

CDW was determined by centrifuging $3 \mathrm{ml}$ of the culture samples at $6000 \mathrm{rpm}$ for $15 \mathrm{~min}$ in a pre-weighed centrifuge tubes, the pellet washed once with $3 \mathrm{ml}$ distilled water, centrifuged and dried at $105^{\circ} \mathrm{C}$ until constant weight was obtained. The centrifuge tube was weighed again to calculate the CDW.

$\mathrm{P}(3 \mathrm{HB}-\mathrm{co}-3 \mathrm{HV})$ concentration analysis was performed using a gas-chromatographic method [5].

In our studies, $\mathrm{P}(3 \mathrm{HB}-\mathrm{co}-3 \mathrm{HV})$ content (wt $\%$ ) was obtained as the percentage of the ratio of $\mathrm{PHA}$ concentration to $\mathrm{CDW}$ [6].

\section{RESULTS AND DICUSSION}

\section{Cell growth and $\mathbf{P}(3 \mathrm{HB}-\mathrm{co-}-3 \mathrm{HV})$ production} in flask cultures using molasses as substrate

The capacities of cell growth and $\mathrm{P}(3 \mathrm{HB}-\mathrm{co}-$ 3HV) synthesis by Yangia sp. ND199 using molasses as substrate were first investigated in flask experiment. The time course of growth and polymer accumulation by Yangia sp. ND199 in HM1 medium revealed that polymer accumulation by the bacterium was initiated from the early stages of growth and was found proportional with cell growth. Maximum CDW of $6.37 \mathrm{~g} / 1, \mathrm{P}(3 \mathrm{HB}-\mathrm{co}-3 \mathrm{HV})$ content of $43.1 \mathrm{wt} \%$ and $\mathrm{P}(3 \mathrm{HB}-\mathrm{co}-3 \mathrm{HV})$ concentration of $2.75 \mathrm{~g} / 1$ were obtained by Yangia after $60 \mathrm{~h}$ of cultivation. The results obtained from this experiment (when molasses was used as carbon source) are comparable with those of the previous report (when pure sugars, such as glucose, sucrose, fructose or glycerol as carbon substrate) [16], suggesting that molasses can be a good carbon substrate for $\mathrm{P}(3 \mathrm{HB}-\mathrm{co}-3 \mathrm{HV})$ production and the growth of Yangia sp. ND199.

\section{$\mathbf{P}(3 \mathrm{HB}-\mathrm{co}-3 \mathrm{BV})$ production in fermentor}

Based on the flask culture results, batch fermentation for $\mathrm{P}(3 \mathrm{HB}-\mathrm{co}-3 \mathrm{HV})$ production by Yangia sp. ND199 using molasses as substrate was performed in 51 fermentor. The results of cell growth rate, PHA content, PHA concentration and sucrose consumption during fermentation are summarized in figure 2. The biomass and PHA accumulation were increased during the cultivation and reached a maximum CDW of $9.1 \mathrm{~g} / 1$, PHA content of $37 \mathrm{wt} \%$ and PHA concentration of $3.35 \mathrm{~g} / 1$ after $33 \mathrm{~h}$ of fermentation. In constrast, the sucrose concentration was decreased during the cultivation and only $1.4 \mathrm{~g} / 1$ of sucrose was remained in the culture medium after $33 \mathrm{~h}$ of fermentation. It was found experimentally that the growth yield coefficent was $0.44 \mathrm{~g}$ cell $/ \mathrm{g}$ sucrose and the product yeild was $0.16 \mathrm{~g} \mathrm{PHA} / \mathrm{g}$ sucrose.

In the fermentor, the $\mathrm{pH}$ and dissolved oxygen concentration were monitored and controlled at optimal condition for bacterial cells growth. For that reason, the growth rate of bacterial cells in the fermentor experiment (9.1 $\mathrm{g} / \mathrm{l}$ after $33 \mathrm{~h}$ growth) is faster than that obtained in the flask experiment $(6.37 \mathrm{~g} / 1$ after $60 \mathrm{~h}$ growth). However, optimum culture conditions may inhibit the accumulation of PHA [1, 12], for that reason the PHA content was decreased from $43.1 \mathrm{wt} \%$ (flask experiment) to $37 \mathrm{wt} \%$ (fermentor experiment). 


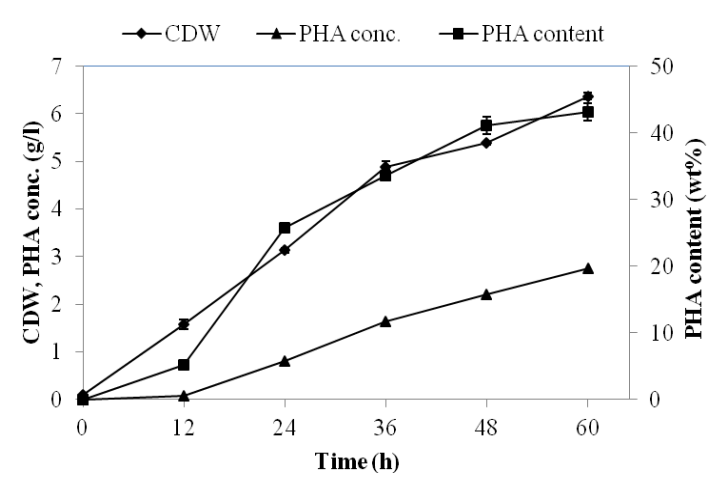

Figure 1. Profiles of CDW, $\mathrm{P}(3 \mathrm{HB}-\mathrm{co}-3 \mathrm{HV})$ content and concentration during cultivation of Yangia sp. ND199 in shake flasks

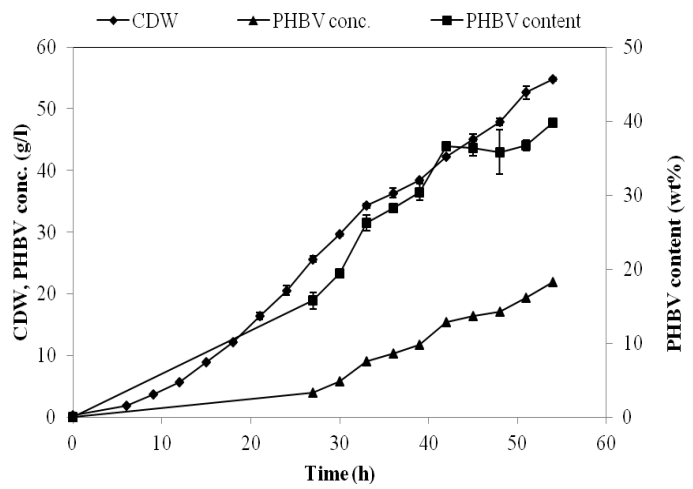

Figure 3. Profiles of CDW, $\mathrm{P}(3 \mathrm{HB}-\mathrm{co}-3 \mathrm{HV})$ content and concentration in a fed-batch fermentation mode using molasses as carbon substrate

Production of $\mathrm{P}(3 \mathrm{HB}-\mathrm{co-}-3 \mathrm{HV})$ by fed-batch cultures with two nutrient feeding strategies

Being an intracellular product, PHA yield is related to that of the biomass. However, the conditions of optimal production of cell mass and PHA are different with respect to the nutrients concentration of the culture medium. The supplement of balance nutrients will be favourable for bacterial cell growth. In constrast, PHAs are usually synthesized within bacterial cells when growth is limited by the deplition of nutrients such as nitrogen, oxygen, and other essential emements but have an excess of carbon source $[1,14]$. In order to get high productivity of PHA, fed-batch cultures of Yangia sp. ND199

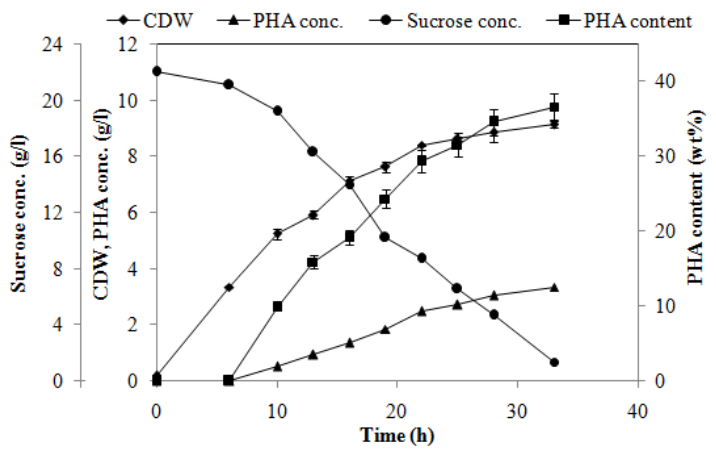

Figure 2. Profiles of CDW, $\mathrm{P}(3 \mathrm{HB}-\mathrm{co}-3 \mathrm{HV})$ content, $\mathrm{P}(3 \mathrm{HB}-\mathrm{co}-3 \mathrm{HV})$ concentration and sucrose concentration during cultivation of Yangia sp. ND199 in a fermentor

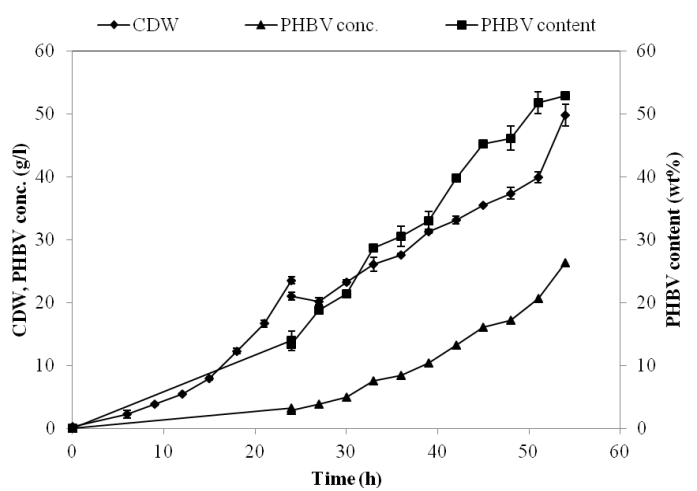

Figure 4. Profiles of CDW, $\mathrm{P}(3 \mathrm{HB}-\mathrm{co}-3 \mathrm{HV})$ content and concentration in a two-step fedbatch fermentation process using molasses and glucose as carbon substrates, respectively

were used to produce $\mathrm{P}(3 \mathrm{HB}-\mathrm{co}-3 \mathrm{HV})$ with two different nutrient feeding strategies. First, all nutrients required for bacterial cells growth are provided to enhance biomass production. Second, to promote the synthesis of polymer, nitrogen limiting conditions were imposed by eliminating yeast extract and peptone from the feed solution II. Figure 3 showed that the biomass and $\mathrm{P}(3 \mathrm{HB}-\mathrm{co}-3 \mathrm{HV})$ content were increased and reached maximum value of 54.8 $\mathrm{g} / 1$ and $39.8 \mathrm{wt} \%$, respectively, after $54 \mathrm{~h}$ of cultivation. The (3HB-co-3HV) productivity obtained after $54 \mathrm{~h}$ of cultivation was $0.4 \mathrm{~g} / \mathrm{l} / \mathrm{h}$. The biomass obtained in this experiment $(54.8$ $\mathrm{g} / \mathrm{l})$ is more higher than that obtained in batch fermentation $(9.1 \mathrm{~g} / \mathrm{l})$. However, the (3HB-co- 
$3 \mathrm{HV})$ content $(39.8 \mathrm{wt} \%)$ is similar to the batch fermentation ( $37 \mathrm{wt} \%)$.

Previous studies have been showed that the use of a complex subtrate, such as yeast extract makes it difficult to control the supply of nutrients for achieving high cell density as well as high PHA content $[11,13]$. Our results obtained in this experiment are in agreement with previous studies, suggesting that the use of molasses (a complex substrat) as carbon substrate can be good for bacterial cell growth, however, it may inhibit the accumulation of PHA. For that reason, comparing the results obtained from these experiments with those of the highest reported so far for PHA production from molasses [8] we found that the PHA content obtained here by Yangia sp. ND199 (39.8 $\mathrm{wt} \%)$ is lower than that obtained by a recombinant Escherichia coli strain (80 wt\%); however, the biomass concentration $(54.8 \mathrm{~g} / \mathrm{l})$ in case of Yangia sp. ND199 is higher than that obtained by E. coli $(39.5 \mathrm{~g} / \mathrm{l})$.

\section{Two-step fed-batch fermentation for $\mathrm{P}(3 \mathrm{HB}$ - co-3HV) production}

In order to get high productivity of PHA, a process comprices two-step fed-batch culture was designed. The first fed-batch step was perfomed under optimal conditions for the growth of Yangia sp. ND199, in wich feed solution I containing molasses as carbon source was used. After $24 \mathrm{~h}$ of cultivation, the biomass $(24 \mathrm{~g} / \mathrm{l})$ was fitrated to remove the inhibitor and transferred to a second fed-batch culture with fresh medium and the feed solution III (nitrogen free and containing glucose, a defined and suitable carbon source for Yangia sp. ND199) was used to promote the biosynthesis of $\mathrm{P}$ (3HBco-3HV). The CDW, P(3HB-co-3HV) content and $\mathrm{P}(3 \mathrm{HB}-\mathrm{co}-3 \mathrm{HV})$ concentration reached after $54 \mathrm{~h}$ of cultivation $(30 \mathrm{~h}$ of cultivation in second step) are summarized in figure 4 . As can be seen from the results, the CDW of $50 \mathrm{~g} / 1$ was achieved after $54 \mathrm{~h}$ of cultivation, lower than that obtained in fed-batch fermentation (54.8 $\mathrm{g} / \mathrm{l})$. However, the accumulation of the P(3HBco-3HV) in the bacterial cells were significantly increased by using two-step fed-batch fermentation, $\mathrm{P}(3 \mathrm{HB}-\mathrm{co}-3 \mathrm{HV})$ content of 52.9 $\mathrm{wt} \%$ and $\mathrm{P}(3 \mathrm{HB}-\mathrm{co}-3 \mathrm{HV})$ productivity of 0.48 $\mathrm{g} / \mathrm{l} / \mathrm{h}$ were obtained after $54 \mathrm{~h}$ of cultivation, 1.33 and 1.2 times higher than those obtained in fed-batch fermentation, respectively. The observation suggests that the use of two-step fed-batch fermentation with two different feed solutions can help to improve $\mathrm{P}(3 \mathrm{HB}-\mathrm{co}-3 \mathrm{HV})$ production by Yangia sp. ND199.

\section{CONCLUSION}

This study showed that the moderate halophile Yangia sp. ND199, isolated recently from the mangroves in Northern Vietnam, was able to use molasses as carbon source for $\mathrm{P}(3 \mathrm{HB}-\mathrm{co}-3 \mathrm{HV})$ production. Fed batch fermentation with two different nutrient feeding strategies or two separate steps was designed for $\mathrm{P}(3 \mathrm{HB}-\mathrm{co}-3 \mathrm{HV})$ production by Yangia sp. ND199. High CDW of $50 \mathrm{~g} / 1, \mathrm{P}(3 \mathrm{HB}-\mathrm{co}-3 \mathrm{HV})$ content of $52.9 \mathrm{wt} \%$ and $\mathrm{P}(3 \mathrm{HB}-\mathrm{co}-3 \mathrm{HV})$ productivity of $0.48 \mathrm{~g} / \mathrm{l} / \mathrm{h}$ were achieved after 54 $\mathrm{h}$ of cultivation using two-step fed-batch fermentation. The process designed here for the production of $\mathrm{P}(3 \mathrm{HB}-\mathrm{co}-3 \mathrm{HV})$ by Yangia sp. ND199 can be developed and used for further studies.

Acknowledgment: This research work is supported by International Foundation for Science (Grant number: F/5021-2).

\section{REFERENCES}

1. Anderson A. J., Dawes E. A., 1990. Occurrence, metabolism, metabolic role, and industrial uses of bacterial polyhydroxyalkanoates. Microbiol. Rev., 54: 450-472.

2. Chen G. Q., 2010. Industrial production of PHA. In: Chen GQ (ed) Plastics from Bacteria Natural Functions and Applications. Springer, Heidelberg Dordrecht London New York, pp. 121-132.

3. Chen G. Q., Wu Q., 2005. The application of polyhydroxyalkanoates as tissue engineering material. Biomaterials, 26: 6565-6578.

4. Choi J., Lee S. Y., 1999. Factors affecting the economics of polyhydroxyalkanoate 
production by bacterial fermentation. Appl. Microbiol. Biotechnol., 51: 13-21.

5. Huijberts G. N. M., van der Wal H., Wilkinson C., Eggink G., 1994. Gaschromatographic analysis of poly(3hydroxyalkanoates) in bacteria. Biotechnol. Tech., 8: 187-192.

6. Lee S. Y., Wong H. H., Choi J., Lee S. H., Lee S. C., Han C. S., 2000. Production of medium-chain-length polyhydroxyalkanoates by high-cell-density cultivation of Pseudomonas putida under phosphorus limitation. Biotechnol. Bioeng., 68: 466470.

7. Lemoigne M., 1926. Produit de déshydratation et de polymérisation de l'acide $\beta$-oxybutyrique. Bull. Soc. Chim. Biol., 8: 770-782.

8. Liu F., Li W., Ridgway D., Gu T., 1998. Production of poly- $\beta$-hydroxybutyrate on molasses by recombinant Escherichia coli. Biotechnol. Lett., 20: 345-348.

9. Philip S., Keshavarz T., Roy I., 2007. Polyhydroxyalkanoates: biodegradable polymers with a range of applications. J. Chem. Technol. Biotechnol., 82: 233-247.

10. Quillaguamán J., Hatti-Kaul R., Mattiasson B., Alvarez M. T., Delgado O., 2004. Halomonas boliviensis sp. nov., an alkalitolerant, moderate halophile bacterium isolated from soil around a Bolivian hypersaline lake. Int. J. Syst. Evol. Microbiol., 54: 721-725.

11. Quillaguamán J., Van-Thuoc D., Guzmán H., Guzmán D., Martín J., Everest A., Hatti-
Kaul R., 2008. Poly(3-hydroxybutyrate) production by Halomonas boliviensis in fedbatch culture. Appl. Microbiol. Biotechnol., 78: 227-232.

12. Roberts M. F., 2005. Organic compatible solutes of halotolerant and halophilic microorganisms. Saline Systems, 1: 5.

13. Thuoc D. V., 2012. Utilization of unsterile medium for production of polyhydroxyalkanoate (PHA) by Yangia sp. ND218. Sci. J. HNUE., 57: 104-110.

14. Valappil S. P., Boccaccini A. R., Bucke C., Roy I., 2007. Polyhydroxyalkanoates in Gram-positive bacteria: insights from the genera Bacillus and Streptomyces. Antonie van Leeuwenhoek, 91: 1-17.

15. Van-Thuoc D., Huu-Phong T., MinhKhuong D., Hatti-Kaul R., 2015. Poly(3hydroxybutyrate-co-3-hydroxyvalerate) production by a moderate halophile Yangia sp. ND199 using glycerol as a carbon source. Appl. Biochem. Bitechnol., 75: 3120-3132.

16. Van-Thuoc D., Huu-Phong T., Thi-Binh N., Thi-Tho N., Minh-Lam D., Quillaguamán J., 2012. Polyester production by halophilic and halotolerant bacterial strains obtained from mangrove soil samples located in Northern Vietnam. MicrobiologyOpen, 1: 395-406.

17. Wu Q., Wang Y., Chen G. Q., 2009. Medical application of microbial biopolyesters polyhydroxyalkanoates. Artif. Cells. Blood. Substit. Immobil. Biotechnol., 37: 1-12. 


\title{
SỬ DỤNG CHỦNG Yangia sp. ND199 \\ TRONG QUI TRÌNH LÊN MEN BÁN LIÊN TỤC SẢN XUẤT POLY (3-HYDROXYBUTYRATE-co-3-HYDROXYVALERATE) TÙ Rİ ĐƯỜNG
}

\author{
Đoàn Văn Thược ${ }^{1}$, Trần Hữu Phong ${ }^{1}$, Đặng Minh Khương ${ }^{2}$ \\ ${ }^{1}$ Trường Đại học Sư phạm Hà Nội \\ ${ }^{2}$ Trường Trung học Phổ thông Bảo Yên 2
}

\section{TÓM TẮT}

Chủng vi khuẩn ưa mặn Yangia sp. ND199 phân lập tại Việt Nam có khả năng chuyển hóa rỉ đường thành poly (3-hydroxybutyrate-co-3-hydroxyvalerate) [P(3HB-co-3HV)]. Khi nuôi cấy trong bình nón, chủng vi khuẩn này có thể tạo ra lượng sinh khối $6,37 \mathrm{~g} / 1$ với hàm lượng $\mathrm{P}(3 \mathrm{HB}-\mathrm{co}-3 \mathrm{HV})$ tích lũy 43,1\% và $2,73 \mathrm{~g} / \mathrm{l}$. Khi nuôi chủng này trong nồi lên men, lượng sinh khối tăng lên $9,1 \mathrm{~g} / 1$ nhưng hàm lượng $\mathrm{P}(3 \mathrm{HB}-\mathrm{co}-3 \mathrm{HV})$ tích lũy lại giảm còn $37 \%$. Phương pháp lên men bán liên tục với 2 chiến lược tiếp dinh dưỡng khác nhau đã được sử dụng. Lượng sinh khối đã tăng lên và đạt $54,8 \mathrm{~g} / 1$ sau 54 h nuôi cấy, tuy nhiên, hàm lượng $\mathrm{P}(3 \mathrm{HB}$-co$3 \mathrm{HV})$ vẫn thấp $(39,8 \%)$. Vì vậy, qui trình lên men 2 pha với 2 chiến lược tiếp dinh dưỡng khác nhau đã được thiết kế. Với qui trình mới này, lượng sinh khối và lượng $\mathrm{P}(3 \mathrm{HB}-\mathrm{co}-3 \mathrm{HV})$ thu được khá cao, lần lượt là $50 \mathrm{~g} / 1$ và $52,9 \%$ sau $54 \mathrm{~h}$ nuôi cấy. Qui trình lên men được thiết kế để sản xuất $\mathrm{P}(3 \mathrm{HB}-\mathrm{co}-3 \mathrm{HV})$ bằng việc sử dụng chủng Yangia sp. ND199 có thể cải tiến và sử dụng cho các nghiên cứu tiếp theo.

Tù̀ khóa: Yangia, $\mathrm{P}(3 \mathrm{HB}-\mathrm{co-3HV})$, lên men bán liên tục, rỉ đường, vi khuẩn ưa mặn.

Ngày nhận bài: 24-6-2015 